\title{
EFFECT OF LAW ENFORCEMENT TO CREATING GOOD GOVERNANCE BASED ON JUSTICE VALUES
}

\author{
Ibnu Affan \\ Islamic University Sumatera Utara \\ ibnu affan@fh.uisu.ac.id
}

\begin{abstract}
The purpose of writing in this article is to find out and analyze the effect of law enforcement in the implementation of good government. The approach method used in normative legal research used in this study uses modern legal concepts. The research result states that the concept of good governance can be realized if governance is organized in a transparent, responsive, participatory manner, obeying legal provisions, oriented to consensus, existence of togetherness, accountability and having a strategic vision. Governance is said to be good if the common goal is carried out well, paying attention to the decision-making process, carrying out regulatory functions, exercising power properly and orderly institutions. Good governance is implemented in the context of democratizing the life of the nation and state. One of the conditions for democratic life is the existence of law enforcement that is just and implemented without a reed perspective. As the first step in creating good governance is to build a sound legal system, both software, hardware, and human resources who run the system.
\end{abstract}

Keyword: Good Governance; Justice Value; Law Enforcement.

\section{A. INTRODUCTION}

Constitution of the Republic of Indonesia of 1945 Article 1 (1) states that Indonesia is a unitary state of the Republic. Then in paragraph (2), and sovereignty vested in the people and exercised in accordance with the Constitution of paragraph (3) Indonesia is a State of Law. In Article 18 paragraph (1) of the Republic of Indonesia is divided over the province and the province is divided into districts / cities that every district / city has a local government, the actual device requires governments in the region as they realized that not all administrative matters can be done by the central government. ${ }^{1}$

The constitution of the Unitary State of the Republic of Indonesia stipulates in Article 1 paragraph (3) of the 1945 Constitution the third amendment that the state of Indonesia is a state of law. Implies that all the behaviors that exist in a country, whether committed by the government and the governed (the people) should be based on the rule of law and not based on power. Law is used as the commander in the life of the state. Law

1 Siti Rodhiyah, Uyunun Nafisa, Implementation Of The Vocation School Of Legislation Agency In Village Consultative Department Agreement (Study of The Implementation The Sriwulan Village BPD Sayung, Demak), Jurnal Pembaharuan Hukum, Volume VI No.1 January-April 2019, page.11-25 
reform efforts in Indonesia have been initiated since the birth of NRI 1945 Constitution can not be separated well from the runway and once the objectives have been formulated as well as in the preamble of the Constitution NRI 1945. The purpose outlined in the Preamble of the 1945 Constitution was briefly is " protect all the people of Indonesia and to promote general welfare based on Pancasila ".2

The ideals of reform that require a new Indonesian democratic government, reforms in the field of law are a top priority. In a democratic country the formation of legislation has a very important element in its formation. ${ }^{3}$ The 1945 Constitution, which has been amended four times, is a positive step in reforming the law.

The development of legal science begins with philosophy and is followed by legal dogmatics (positive law). Between the two there is a sharp difference. Philosophy of law is highly speculative, whereas positive law is highly technical. So to bridge the two, a legal theory is needed which was originally in the form of general law teachings (algemene rechts/eer). Legal theory contains general characteristics such as legal principles and the same problems from various legal systems. ${ }^{4}$

Law enforcement is essentially a process to realize legal goals, legal ideas become reality. ${ }^{5}$ Meanwhile, according to Satjipto Rahardjo, ${ }^{6}$ Law enforcement is essentially a problem that is not simple, not only because of the complexity of the legal system itself, but also the complexity of the relationship between the legal system and the social, political, economic and cultural systems of society.

One of the characteristics of good law enforcement is reflected in the orderly administration in the law enforcement process as well as the integration and harmony between law enforcement officers, especially in the criminal justice system known as the integrated criminal justice system. The integration between law enforcement officers should not be misinterpreted so that it only prioritizes cooperation between law enforcement officers which can lead to bias that leads to administrative irregularities or even violations of the law. Cooperation between law enforcement agencies is intended to facilitate law enforcement efforts in accordance with the principles of fast, simple and low cost as well as free, honest and impartial in the settlement of cases. In other words, integration is intended to create

2 Ninuk Triyanti, Re-Actualization of Pancasila Values On Law Establishment In The Economic Globalization Era, Jurnal Pembaharuan Hukum, Volume VI No.2 April-August 2019, page.214225

3 Siti Rodhiyah, Muhammad Harir, Peranan Badan Permusyawaratan Desa (Bpd) Dalam Pembentukan Peraturan Desa Di Desa Krandon Kecamatan Guntur Kabupaten Demak, Jurnal Pembaharuan Hukum, Volume II No. 2 May-August 2015, page.291-300

4 Philipus M. Hadjon, Tatiek Sri Djatmiati, Argumentasi Hukum, Gadjah Mada University Press, Yogyakarta, 2009, page. 9.

5 Esmi Warassih, Pranata Hukum Sebuah Telaah Sosiologis, Suryandaru Utama,Semarang, 2005, page. 83

6 Satjipto Rahardjo, Penegakan Hukum, Tinjauan Sosiologis, Genta Publishing, Yogyakarta, 2009, page. 8 
effectiveness and efficiency which is another characteristic of good governance while always paying attention to law and orderly administration.

Law enforcement reform as one of the reform agendas demanded by the community not only requires improvements in legal materials or regulations, but also increases the performance of law enforcement officers. The sensitivity of law enforcement officers must be clearly reflected in the pattern of behavior and professionalism as well as the performance of law enforcement officers which is a reflection of the Principle of Professionalism.

The purpose of this paper is to find out and analyze the influence of law enforcement in the implementation of good government, and the implementation of law in Indonesia is often understood from a different perspective. Legal problems in Indonesia arise due to several things, both from the judicial system, legal instruments, inconsistencies in law enforcement, power intervention and legal protection. Many cases involve the authorities or law enforcement officers who are biased before entering court or being acquitted by judges. This will lead to an understanding of public distrust of the law.

\section{B. RESEARCH METHODS}

The method used is a normative juridical approach method. That is research that explains the provisions in the applicable laws and regulations, is related to the reality in the field, then analyzed by comparing the demands of the ideal values that exist in the legislation with the reality in the field. ${ }^{7}$ This type of research is descriptive analysis, because the researcher wants to describe or explain the subject and object of research, which then analyzes and finally draws conclusions from the results of the study. ${ }^{8}$

\section{RESULTS AND DISCUSSION}

\section{Law Enforcement towards the value of justice}

Montesquieu divides power into three areas, namely the executive, judicial and legislative, which is hereinafter known as the Trias Politica. Indonesia based on the 1945 Constitution does not adhere to the Trias Politica understanding. However, the institutionalization of various state powers clearly shows that the formulators of the 1945 Constitution were strongly influenced by the teachings of the Trias Politica. ${ }^{9}$ The institutionalization of various state powers in the 1945 Constitution is not strictly separated which will lead to checking power with power. However, each institution holding power still has linkages and coordination (checks and balances).

7 Ronny Hanitijo Soemitro, Metodologi Penelitian Hukum dan Jurimetri, Ghalia Indonesia, Jakarta, 1990, page. 33.

8 Mukti Fajar ND dan Yulianto Achmad, Dualisme Penelitian Hukum Normatif dan Empiris, Pustaka Pelajar, Yogyakarta, 2010, page. 183.

9 Moh. Mahfud MD, Pergulatan Politik dan Hukum diIndonesia, Gama Media, Yogyakarta, 1999, page. 274. 
Law enforcement in Indonesia is currently still far from expectations, the picture of law enforcement is often applied without the value of justice. Justice is what we want to realize in the law enforcement process. But there are still many judges who in law enforcement always use the law. Law enforcement that always uses the law has its limitations. Because judges will only use the law in resolving cases, and do not explore the values that live in society (living law). Judges are independent and impartial in resolving cases. This means that judges are free according to the law in deciding cases and there is no outside interference. Whereas in the Law on Judicial Power it is stated that judges are obliged to explore the values that live in society. ${ }^{10}$

Law enforcement that is oriented to the law, the justice that is realized is only formal justice based on the law (procedural justice). If it has fulfilled the elements in an article, the judge will give a decision. Legal justice often injures substantial public justice. Because the justice that is realized (procedural) is not like the justice (substantive) that justice seekers want. So the limitation of conventional law enforcement is that it cannot realize substantive justice, namely justice that justice seekers want.

According to Soerjono Soekamto, the law can function properly, it requires harmony and the relationship between four factors, namely: ${ }^{11}$

a. The laws and regulations themselves.

The possibility is that there is a discrepancy in the laws and regulations regarding certain areas of life. Another possibility is the incompatibility between the legislation and the unwritten law or customary law. Sometimes there is a discrepancy between written law and customary law, and so on.

b. Mentality of officers who enforce the law.

Law enforcers include judges, police, prosecutors, defenders, correctional officers, and so on. If the legislation is good, but if the mentality of law enforcement is not good, it will happen to the law enforcement system.

c. Facilities that are expected to support the implementation of the law. If the laws and regulations are good and the mentality of the enforcers is good, but the facilities are inadequate, then law enforcement will not work properly.

d. Awareness and legal compliance of the citizens.

According to Lawrence Friedman, there are three elements in the legal system, namely structure, substance and legal culture. ${ }^{12}$ Obstacles

10 Haryono, Penegakan Hukum Berbasis Nilai Keadilan Substantif (Studi Putusan MK No. 46/PUU-VII/2012 Dated 13 February 2012), Jurnal Hukum Progresif, Vol. 7, No. 1, April 2019, page.20-39

11 Soerjono Soekamto, Teori Sosiologi tentang Pribadi dalam Masyarakat, Ghalia Indonesia, Jakarta, 1998, page.83-84.

12 Achmad Ali, Keterpurukan Hukum di Indonesia Penyebab dan Solusinya, Ghalia Indonesia, Ciawi-Bogor, Second Printing, 2005, page.1. 
in law enforcement in Indonesia are caused by the slump in the three elements of the legal system that have shifted from the ideals in the 1945 Constitution. As the highest source of law, the 1945 Constitution has outlined the basis for the implementation of good governance.

a. Legal Substance

Substance also means the products produced by people who are in the legal system which includes the decisions they make, the new rules they make. Substance also includes living law, not just the rules contained in law books. ${ }^{13}$ Ideally, the national legal order leads to the creation of a national legal order that can ensure good governance of the state and relations between citizens, the government and the international community. The goal of legal politics is to create a national legal system that is rational, transparent, democratic, autonomous and responsive to the development of people's aspirations and expectations, not a legal system that is oppressive, orthodox and reductionistic. ${ }^{14}$

Legal substance is related to the process of making a legal product carried out by legislators. Values that have the potential to cause legal symptoms in the community are formulated in a statutory regulation. While the manufacture of a product of legislation is influenced by the political atmosphere in a country.

Often the legal substance contained in a product of legislation is influenced by the interests of certain groups. So that the resulting law is not responsive to the development of society. The wider consequence is that the law is used as a tool of power and not as a controller of power or limiting the arbitrariness of those in power.

Legislation is made by the power granted by the law. According to the 1945 Constitution, the power to make laws is given to the DPR as the legislature and the President as the executive. Article 5 paragraph (1) of the 1945 Constitution states that "the President has the right to submit a draft law to the House of Representatives". Article 20 paragraph (1) of the 1945 Constitution states that "The House of Representatives holds the power to form laws". ${ }^{15}$ The draft law is discussed jointly between the DPR and the President for mutual approval. According to Satjipto Rahardjo who quoted from Radbruch, there are basic values of law, namely Justice, Usefulness and Legal Certainty. ${ }^{16}$ Not infrequently these three basic legal values contradict each other in law enforcement. If this happens, justice must be prioritized, considering the purpose of law is to create a sense of justice in society.

b. Legal Structure

13 Ibid, page. 2.

14 Imam Syaukani, A. Ahsin Thohari, Dasar-dasar Politik Hukum, PT Rajagrafindo Persada, Jakarta, 2008, page. 72.

15 First Amendment to the Constitution.

16 Satjipto Rahardjo, IImu Hukum, PT Citra Aditya Bakti, Bandung, Fifth printing, 2000, page 19. 
The structure is the framework or framework, the part that survives, the part that gives some form and limitation to the whole. ${ }^{17}$ The legal structure is an institutionalization into the legal existence. The legal structure here includes state law enforcement agencies such as courts, prosecutors, police, advocates and law enforcement agencies specifically regulated by law such as the KPK. The authority of law enforcement agencies is guaranteed by law. So that in carrying out their duties and responsibilities apart from the influence of government power and other influences.

Included in the legal structure is the general judicial hierarchy in Indonesia and structural elements which include the number and types of courts, their jurisdictions, the number of Supreme Court justices and other judges. Freedom of the judiciary is essential than a state of law, so that the upholding of the principles of a state of law is largely dependent on the presence or absence of judicial freedom in that state. ${ }^{18}$ As a parameter for implementing democracy, the freedom of the judiciary in examining and deciding cases must be guaranteed by the constitution.

The Supreme Court as the highest judicial body which is not only the last place to determine the law in a concrete sense but also as a place to give birth to new legal principles and rules as well as new theories regarding the law. ${ }^{19}$ The Supreme Court also has the authority to cancel decisions or decisions of courts from all judicial circles at the cassation level, as mandated in Article 30 paragraph (1) of Act No. 5 of 2004 concerning Amendments to Act No. 14 of 1985 concerning the Supreme Court.

The control function of the Supreme Court has an important meaning for law enforcement efforts in Indonesia because with the effective control function, law enforcement efforts will be more secure. It is unfortunate that even though this function is still running, it is not very effective, even now there are many case brokers hanging around the Supreme Court.

Law enforcers in charge of implementing the law cover a very broad scope, including; upper, middle and lower strata. The point is to what extent officers must have a guideline, one of which is written regulations covering the scope of their duties. In law enforcement, it is possible that law enforcers face the following: ${ }^{20}$

1) To what extent are officers bound by existing regulations,

2) To what extent is the officer willing to provide policy,

3) What kind of example should the officer give to the community?

4) To what extent is the degree of synchronization of assignments given to officers so as to provide firm limits on their authority?

17 Achmad Ali, Op Cit.

18 Abdurrahman, SH, Aneka Masalah dalam Praktek Penegakan Hukum di Indonesia, Alumni, Bandung, 1980, page.1.

19 Bagir Manan, Teori dan Politik Konstitusi, FH. UI Press, Yogyakarta, 2004, page.116.

20 Zainuddin, Filsafat Hukum, Sinar Grafika, Jakarta, 2006, page.95. 
Weak mentality of law enforcement officers resulted in law enforcement not running properly. Many factors affect the weak mentality of law enforcement officers including weak understanding of religion, economics, recruitment processes that are not transparent and so on. So it can be emphasized that law enforcement factors play an important role in the functioning of the law. If the regulations are good, but the quality of law enforcement is low, then there will be problems. Likewise, if the regulations are bad while the quality of law enforcement is good, the possibility of problems arising is still open.

c. Legal Culture

Legal culture according to Lawrence Meir Friedman is human attitudes towards the law and the legal system-beliefs, values, thoughts, and expectations. Legal culture is the atmosphere of social thought and social forces that determine how the law is used, avoided, or abused. ${ }^{21}$

The law is believed to be a strong balancing institution against the threat of disintegration in social life due to the clash of forces that both want to be in power and at the same time limit the arbitrariness of those in power. Law in its original form is limiting power and seeks to allow for a balance in social life. In contrast to aggressive and expansionist power, the law tends to be compromising, peaceful and full of agreements in social and political life. ${ }^{22}$

The law can work according to its function if the community is obedient and subject to the applicable law. This does not mean that dispute resolution in the community outside of legal institutions is not justified. The Constitution itself recognizes this, namely in Article 18B paragraph (2) of the 1945 Constitution which states that: The state recognizes and respects customary law community units and their traditional rights as long as they are still alive and in accordance with community development and the principles of the Unitary State of the Republic of Indonesia regulated in law. ${ }^{23}$

People who submit their legal disputes or problems to legal institutions unless driven by interests can also be seen from factors such as ideas, attitudes, beliefs, hopes and opinions regarding the law. People consciously come to the law (court) due to a positive assessment of legal institutions. Thus, the decision to bring the dispute to court is essentially a positive result of the work of these various factors. ${ }^{24}$

Both legal substance, legal structure and legal culture are interrelated with one another and cannot be separated. In its implementation between the three, a mutually supportive relationship

21 Achmad Ali, Op Cit, page.2.

22 Peter Mahmud Marzuki, Pengantar IImu Hukum, Prenada Media Group, Jakarta, 2009, page 83.

23 Second Amendment to the Constitution.

24 Satjipto Rahardjo, Op Cit, page.154-155. 
must be created in order to create a safe, orderly, peaceful and peaceful lifestyle.

\section{The Effect of Law Enforcement on the Implementation of Good Governance}

Ubi sociates ibi ius where there is society there is law. Law is not a static institution, law changes from time to time. Law develops in accordance with the development of society. The emergence of the concept of the Rule of Law was not sudden but the result of several processes of legal development in the world.

Currently, countries in the world, including Indonesia, are generally included in the category of modern law. According to Satjipto Rahardjo, modernity has the following characteristics: ${ }^{25}$

a. Have a written form.

b. The law applies to the entire territory of the country.

c. Law is an instrument that is used consciously to realize the political decisions of its people.

Law as a means of reform in society can be observed from the products of legislation and jurisprudence. In a country that adheres to a civil law legal system, this legal function will be felt, because the civil law system emphasizes statutory regulations. So that to achieve reform in society that leads to the creation of welfare, good laws are needed in accordance with the laws that live in society or reflect the values that live in society.

The creation of fair law enforcement is closely related to the implementation of good governance. To move towards modern law, there needs to be improvements in government through good governance. Good governance according to the Institute of State Administration is the process of administering state power in implementing the provision of public good and service. Pinto defines governance as the practice of exercising power and authority by the government in the management of government affairs in general and economic development in particular. ${ }^{26}$

Good Governance began to emerge in Indonesia after the reformation era. It is motivated by a wide range of problems that arise government demands that the president of the new order as a center of power as a result of the constitution as well as a result of other state institutions that do not go well, and also blockage of social control that comes from community participation. But in fact, until now still have not found a good abiding about what is good governance so that in its implementation, this concept has not been able to run well. The

25 Ibid, page.213-214.

26 Sadjijono, Fungsi Kepolisian dalam Pelaksanaan Good Governance, LaksBang Yogyakarta, Yogyakarta, Second printing, 2005, page.180. 
government began to have commitment to make good governance as the basis or foundation of the value of government. ${ }^{27}$

Good governance is implemented in the context of democratizing the life of the nation and state. One of the conditions for democratic life is the existence of fair and impartial law enforcement. As the first step in the creation of good governance is to build a sound legal system, both software, hardware, and human resources that run the system (human ware). ${ }^{28}$ Manifestation of good governance is a solid state governance and responsible, and efficient, effectively, by keeping the 'Sinergity' constructive interaction between the domains of the state, the private sector and the public (society). ${ }^{29}$

If the power of the state exceeds the power of society (civil society) and the market, the value assessed will not grow because it is dictated and controlled by state power. If the market is too strong power, beyond the power of civil society and the state, it means that the power is money or the capitalists who decides everything in lifely society and state. However, if power is the dominant civil society while the state and the market is weak, then that will happen is the coexistence of chaos, mess, without a government, which develop without a clear direction. ${ }^{30}$

The purpose of law enforcement, among others, is to guarantee legal certainty which is also one of the general principles of state administration. Every action by law enforcement officers at the level of investigation, investigation, prosecution, as well as legal remedies, executions and examinations must always adhere to the rule of law which is also a characteristic of good governance. Law enforcement is not only intended to impose penalties on every violator of the law, law enforcement is also intended so that its implementation must always be guided by the procedures or procedures outlined by law by taking into account the legal culture that lives in the community, especially must be able to capture a living sense of justice in society.

In the framework of the implementation efforts of law enforcement to create good governance to people need to be implemented the renewal of some of the regulation to improve the existing legal system in order to achieve a fair society and peaceful, with the improvement of regulations for law enforcement officers then each party is expected to implement their respective duties, functions and

27 Fitria Andalus Handayani, Mohamad Ichsana Nur, Implementasi Good Governance di Indonesia, Publica: Jurnal Pemikiran Administrasi Negara, Vol 11 No.1 June 2019, page.111

28 Sadjijono, Op.Cit, page.189.

29 Muhammad Ansori Lubis, Ria Sinta Dhevi, Muhammad Yasid, Penegakan Hukum Terhadap Aparat Sipil Negara Yang Melakukan Pelanggaran Hukum Dalam Mewujudkan Good Governance, Jurnal Darma Agung, Vol 28, No 2, August 2020, page 269-285

30 Muhammad Ilham Arisaputra, Penerapan Prinsip-Prinsip Good Governance Dalam Penyelenggaraan Reforma Agraria Di Indonesia, Yuridika, Vol 28 No 2, May-August 2013, page.188-216 
authorities in a responsible manner, the implementation cannot be separated from the supervision of the government and the community.

Law enforcement is something that cannot be separated from measuring the success of law enforcement in Indonesia. According to Utilitarianism, law enforcement has a purpose based on certain benefits (benefit theory or theory of purpose), and is not just avenging the actions of criminals, not just to retaliate or reward people who commit crimes, but has certain useful purposes. Benefit here is defined as happiness. A good law is a law that brings happiness to many people. ${ }^{31}$ Law enforcement that has been based on the element of expediency will increase good governance towards the value of justice

\section{CONCLUSION}

The research result states that the concept of good governance can be realized if governance is organized in a transparent, responsive, participatory manner, obeying legal provisions, oriented to consensus, existence of togetherness, accountability and having a strategic vision. Governance is said to be good if the common goal is carried out well, paying attention to the decision-making process, carrying out regulatory functions, exercising power properly and orderly institutions. Good governance is implemented in the context of democratizing the life of the nation and state. One of the conditions for democratic life is the existence of law enforcement that is just and implemented without a reed perspective. As the first step in creating good governance is to build a sound legal system, both software, hardware, and human resources who run the system. In law enforcement must be based on values of justice because of the nature of law enforcement is the realization of justice for the people, the rule of law is a means for the realization of social justice for all Indonesian people, as stated in the ideals of the Indonesian nation.

\section{Books :}

\section{BIBLIOGRAPHY}

Abdurrahman, 1980, Aneka Masalah dalam Praktek Penegakan Hukum di Indonesia, Alumni, Bandung;

Achmad Ali, 2005, Keterpurukan Hukum di Indonesia Penyebab dan Solusinya, Ghalia Indonesia, Second Printing Ciawi-Bogor;

Bagir Manan, 2004, Teori dan Politik Konstitusi, FH. UI Press, Yogyakarta;

Esmi Warassih, 2005, Pranata Hukum Sebuah Telaah Sosiologis, Suryandaru Utama, Semarang;

Imam Syaukani, A. Ahsin Thohari, 2008, Dasar-dasar Politik Hukum, PT Rajagrafindo Persada, Jakarta;

31 Hasaziduhu Moho, Penegakan Hukum di Indonesia Menurut Aspek Kepastian Hukum, Keadilan dan Kemanfaatan, Jurnal Warta, Edition 59 January 2019, page.1-13 
Lembaga Administrasi Negara dan Badan Pengawasan Keuangan dan Pembangunan, 2000, Akuntabilitas dan good Governance, Jakarta;

Moh. Mahfud MD, 1999, Pergulatan Politik dan Hukum diIndonesia, Gama Media, Yogyakarta;

Mukti Fajar ND dan Yulianto Achmad, 2010, Dualisme Penelitian Hukum Normatif dan Empiris, Pustaka Pelajar, Yogyakarta;

Peter Mahmud Marzuki, 2009, Pengantar IImu Hukum, Prenada Media Group, Jakarta;

Philipus M. Hadjon, Tatiek Sri Djatmiati, 2009, Argumentasi Hukum, Gadjah Mada University Press, Yogyakarta;

Ronny Hanitijo Soemitro, 1990, Metodologi Penelitian Hukum dan Jurimetri, Ghalia Indonesia, Jakarta;

Sadjijono, 2005, Fungsi Kepolisian dalam Pelaksanaan Good Governance, LaksBang Yogyakarta, Second printing, Yogyakarta;

Satjipto Rahardjo, 2000, IImu Hukum, PT Citra Aditya Bakti, Fifth print, Bandung;

Satjipto Rahardjo, 2009, Penegakan Hukum, Tinjauan Sosiologis, Genta Publishing, Yogyakarta;

Soerjono Soekamto, 1998, Teori Sosiologi tentang Pribadi dalam Masyarakat, Ghalia Indonesia, Jakarta;

Zainuddin, 2006, Filsafat Hukum, Sinar Grafika, Jakarta;

\section{Journals :}

Fitria Andalus Handayani, Mohamad Ichsana Nur, Implementasi Good Governance di Indonesia, Publica: Jurnal Pemikiran Administrasi Negara, Vol 11 No.1 June 2019;

Haryono, Penegakan Hukum Berbasis Nilai Keadilan Substantif (Studi Putusan MK No. 46/PUU-VII/2012 Dated 13 February 2012), Jurnal Hukum Progresif, Vol. 7, No. 1, April 2019;

Hasaziduhu Moho, Penegakan Hukum di Indonesia Menurut Aspek Kepastian Hukum, Keadilan dan Kemanfaatan, Jurnal Warta, Edition 59 January 2019;

Muhammad Ansori Lubis, Ria Sinta Dhevi, Muhammad Yasid, Penegakan Hukum Terhadap Aparat Sipil Negara Yang Melakukan Pelanggaran Hukum Dalam Mewujudkan Good Governance, Jurnal Darma Agung, Vol 28, No 2, August 2020;

Muhammad Ilham Arisaputra, Penerapan Prinsip-Prinsip Good Governance Dalam Penyelenggaraan Reforma Agraria Di Indonesia, Yuridika, Vol 28 No 2, May-August 2013; 
Ninuk Triyanti, Re-Actualization of Pancasila Values On Law Establishment In The Economic Globalization Era, Jurnal Pembaharuan Hukum, Volume VI No.2 April-August 2019;

Siti Rodhiyah, Muhammad Harir, Peranan Badan Permusyawaratan Desa (BPD) Dalam Pembentukan Peraturan Desa Di Desa Krandon Kecamatan Guntur Kabupaten Demak, Jurnal Pembaharuan Hukum, Volume II No. 2 May-August 2015;

Siti Rodhiyah, Uyunun Nafisa, Implementation Of The Vocation School Of Legislation Agency In Village Consultative Department Agreement (Study of The Implementation The Sriwulan Village BPD Sayung, Demak), Jurnal Pembaharuan Hukum, Volume VI No.1 JanuaryApril 2019. 